International Journal of Current Microbiology and Applied Sciences

ISSN: 2319-7706 Volume 9 Number 2 (2020)

Journal homepage: http://www.ijcmas.com

Original Research Article

https://doi.org/10.20546/ijcmas.2020.902.264

\title{
Economics of Different Insecticidal Treatments against Diamondback Moth on Cabbage
}

\author{
Purushotam Sharma*, Hitesh Jangir, Deepika Yadav and Sanwar Mal Jat \\ Department of Agricultural Entomology, S.K.N. College of Agriculture Jobner, \\ Jaipur 303328, India \\ *Corresponding author
}

Keywords

Economics,

diamond backmoth, insecticides, cabbage

Article Info

Accepted:

18 January 2020

Available Online:

10 February 2020

\section{A B S T R A C T}

The data on economics of different insecticidal applications against diamondback moth (Plutella xylostella L) at different intervals revealed that, the maximum yield of cabbage heads was registered in the plots treated with Spinosad 45 Sc (195.67q/ ha), which was found at par with indoxacarb 14.5 Sc (192.23q/ ha), the latter treatment was also nonsignificant with flubendiamide $39.35 \mathrm{Sc}(184.47 \mathrm{q} / \mathrm{ha})$. The minimum yield was observed in pyridalyl $10 \mathrm{Ec}(155.47 \mathrm{q} / \mathrm{ha})$ and acephate $75 \mathrm{Sp}$ (158.60q/ ha). All the treatment were significantly superior over control $(138.50 \mathrm{q} / \mathrm{ha})$. The order of yield revealed by different treatments was spinosad $=$ indoxacarb $\geq$ flubendiamide $\geq$ emamectin benzoate $\geq$ chlorantraniliprole $\geq$ fipronil $=$ chlorfenapyr $>$ acephate $=$ pyridalyl $>$ control.

\section{Introduction}

Cabbage, Brassica oleracea var. capitata L. is one of the important cruciferoet aus vegetable crops grown in India. It is grown more or less in all the states and is used as salad, boiled vegetable, in curries, pickling as well as dehydrated vegetable. $\mathrm{T}$ he total area under cultivation of cabbage in India is 372 thousand hectares with an annual production to the tune of 8534 thousand tonnes with productivity of 18.3 metric tonnes (Anonymous-2013). The total area under cultivation of cabbage in Rajasthan is 346 hectares with an annual production to the tune of 7588 tonnes. (Anonymous-2010). China is major cabbage producing country with 47 per cent of world followed by India with 12 per cent of world production ${ }^{[2]}$.

To evolve effective management strategy it is pertinent to study the abiotic factors of environment in relation to pest population. The study was aimed in order to find out the correlation of diamondback moth population and natural enemies in cabbage ecosystem with the abiotic parameters to know the hospitable conditions for insect development. 
Insecticides are used widely to control the insect pests of vegetables because of the easy adoption, effectiveness and immediate control. Indiscriminate and irrational use of chemical insecticides at higher dosages results in resurgence, resistance and residual problems.

The diamondback moth is a first crop pest reported to be resistant to DDT and now to almost insecticides including biopesticides. The judicious use of chemicals with novel mode of action needs to be implemented to manage this insect pest. There are many insecticides which have different mode of action than the conventional ones. The diamide insecticides such as chlorantraniliprole and flubendiamide a new class of insecticides that selectively target insect ryanodine receptor (RyR), a distinct class of homo-tetrameric calcium release channel which play pivotal role in calcium homeostasis in numerous cell types.

Similarly the pyrroles, and phenyl pyrazole insecticides block the GABA and glutamate gated chloride channels. These novel insecticides in conjuction with other IPM approaches may play a pivotal role in devising effective management strategy against diamondback moth.

A perusal of literature from all sources of information revealed that a meagre work has been done on seasonal the adverse effect on natural enemies in cabbage ecosystem in Rajasthan.

\section{Experimental details}

The materials used and methodologies adopted during the course of investigation on 'Seasonal abundance and management of diamondback moth, Plutella xylostella(.L) on Brassic cabbage a.var oleracea L capitata'. as envisaged in the plan of work has been described in this chapter.

\section{Site and location of experiments}

The present investigations were conducted at Horticulture Farm of S.K.N. College of Agriculture, Jobner, Jaipur during Rabi, 201516. Geographically, Jobner is located at longitude of $75^{\circ} 28^{\prime}$ East, latitude of $26^{\circ} 06^{\prime}$ North and at an altitude of 427 metres above mean sea level (MSL) in Jaipur district of Rajasthan.

\section{Climatic and weather conditions of location}

The climate of the region is typically semiarid which is characterized by extremes of the temperature both during summer and winter. During summer, temperature may rise as high as $47^{\circ} \mathrm{C}$ and in winter, it may fall as low as $2-$ $3{ }^{0} \mathrm{C}$. The total rainfall is $500 \mathrm{~mm}$ which is mostly received from last week of June to September. This region provides a safe long growing season for most of the crops.

\section{Soil}

The alluvial soils are present in Western and Northern parts of Jaipur, whereas sierozem soils are present in Eastern parts of Jaipur. The site of experiment was in Western part of Jaipur district.

\section{Preparation of nursery beds and sowing of seeds}

Cabbage seedlings were raised in nursery beds. Nursery beds of size $2 \times 1 \mathrm{~m}^{2}$ size were prepared by mixing well rottened farm yard manure in the soil @ $10 \mathrm{~kg}$ per square meter. Prior to sowing, seeds were treated with thiram@2 gm per kg of seed. The seed of variety Golden Acre were sown at the rate of $500-600 \mathrm{~g} \mathrm{ha}^{-1}$ in seed beds on $15^{\text {th }}$ September, 2015. To avoid mortality of seedlings due to damping off, drenching of 
the beds was done with Bavistin@15 g per litre of water.

\section{Preparation of field and manuring}

The experimental field was thoroughly ploughed and cross ploughed with the help of tractor operated plough, followed by planking and leveling to bring good tilth. Beds $(2.25 \mathrm{x}$ $2.25 \mathrm{~m}^{2}$ ), paths and channels were prepared according to the layout of the experiments. The recommended dosages of NPK were applied in the ratio of $80: 80: 60 \mathrm{~kg} \mathrm{ha}^{-1}$.

Well rotten FYM was incorporated in the soil at the time of field preparation @ $25 \mathrm{t} \mathrm{ha}^{-1}$ Nitrogen was applied through urea, half as basal dose and remaining half in two equal splits after 30 and 50 days of transplanting. Phosphoric and potassic fertilizers were applied through single super phosphate and Murate of Potash, respectively just before transplanting.

\section{Transplanting}

Five weeks old seedlings were transplanted at row to row and plant to plant distance of $45 \mathrm{x}$ $45 \mathrm{~cm}$, respectively. The transplanting was done on $20^{\text {th }}$ October during Rabi, 2015-16 in the evening hours followed by light irrigation. Other cultural practices as recommended in Packages of Practices were followed during the experimental period.

\section{Materials and Methods}

Healthy cabbage heads were harvested when they reached appropriate marketable size and their weight from each treatment was expressed as marketable yield in quintal per hectare and subjected to analysis of variance.

The avoidable loss and increase in yield of cabbage heads over control were calculated for each treatment by the following formula (Pradhan1964):

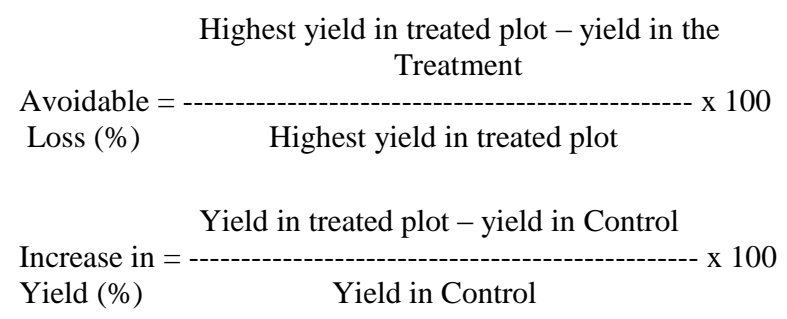

The per cent protection efficiency and yield loss in individual treatment was worked out by taking into account the mean head yield of best treatment and the fruit yield of individual treatment.

The gross return was worked out by multiplying the yield with the wholesale price of cabbage prevailing in the market at the time of harvesting. The net return and benefitcost ratio was worked out by taking in to account the expenditure on individual insecticidal treatment and the corresponding yield in to account.

\section{Results and Discussion}

\section{Yield of cabbage heads}

The data presented in table 4.5 revealed that in all the plots the yield of cabbage heads in all the treated plots were significantly higher over control during Rabi, 2015-16. The maximum yield of cabbage heads (195.67 q $\mathrm{ha}^{-1}$ ) was obtained from the plots treated with spinosad followed by indoxacarb (192.33 q $\mathrm{ha}^{-1}$ ) which were statistically at par.

These treatments were followed by the plots treated with flubendiamide (184.47 q ha $\mathrm{qa}^{-1}$, and emamectin benzoate (180.95 q ha-1), chlorantraniliprole $\left(175.30 \mathrm{q} \mathrm{ha}^{-1}\right)$, fipronil $\left(175.20 \mathrm{q} \mathrm{ha}^{-1}\right)$ and chlorfenapyr, (172.23 q ha $\left.^{-1}\right)$.

The minimum yield was obtained from the plots treated with pyridalyl (155.47 $\left.\mathrm{q} \mathrm{ha}^{-1}\right)$ followed by acephate (158.60 q ha $\left.{ }^{-1}\right)$, which were statistically at par with each other. 
Assessment of losses and increase in yield over control

In the plots treated with spinosad, the total avoidable loss and per cent avoidable loss were zero (Table 4.5) followed by indoxacarb with the total avoidable loss of $3.44 \mathrm{q} \mathrm{ha}^{-1}$ and per cent avoidable losses of 1.75 per cent. the maximum total avoidable losses $\left(54.70 \mathrm{q} \mathrm{ha}^{-1}\right)$ and per cent avoidable losses $(27.95 \%)$ were recorded in untreated control plots, followed by pyridalyl (40.20 $\mathrm{q} \mathrm{ha}^{-1}$ and $\left.20.54 \%\right)$. and acephate (37.07 $\mathrm{q} \mathrm{ha}^{-1}$ and $\left.18.94 \%\right)$.

In the treatments of flubendiamide, emamectin benzoate, chlorantraniliprole, fipronil and chlorfenapyr, the total avoidable losses were 11.20, 14.72, 20.37, 20.47, 23.44 and $24.25 \mathrm{q} \mathrm{ha}^{-1}$ and per cent avoidable losses were 5.72, 7.52, 10.41, 10.46 and 11.97 per cent, respectively. The maximum total increase in yield $\left(57.17 \mathrm{q} \mathrm{ha}^{-1}\right)$ and per cent increase in yield $(41.28 \%)$ over untreated control was recorded in the plots treated with spinosad followed by indoxacarb $\left(53.73 \mathrm{q} \mathrm{ha}^{-1}\right.$ and $38.80 \%$ ). the total and per cent increase in yield over control in the treatments flubendiamide, emamectin benzoate, chlorantraniliprole, fipronil and chlorfenapyr were $45.97,42.45,36.80,36.70$ and $33.73 \mathrm{q}$ $\mathrm{ha}^{-1}$ and 33.19, 30.64, 26.57, 26.50 and 24.35 per cent, respectively.

The minimum increase in yield $\left(16.97 \mathrm{q} \mathrm{ha}^{-1}\right)$ and per cent increase in yield (12.25\%) over control were recorded in the plots treated with pyridalyl followed by acephate $\left(20.10 \mathrm{q} \mathrm{ha}^{-1}\right.$ and $14.51 \%$ ).

Table.1 Details of insecticides used

\begin{tabular}{|c|c|c|c|c|}
\hline S. No. & Insecticides & Formulations & $\begin{array}{c}\text { Trade } \\
\text { Name }\end{array}$ & Conc. (\%) \\
\hline 1. & Spinosad & $45 \mathrm{SC}$ & Tracer & 0.01 \\
\hline 2. & Indoxacarb & $14.5 \mathrm{SC}$ & Avaunt & 0.01 \\
\hline 3. & Chlorantraniliprole & $18.5 \mathrm{SC}$ & Coragen & 0.005 \\
\hline 4. & Emamectin benzoate & $5 \mathrm{SG}$ & Proclaim & 0.005 \\
\hline 5. & Chlorfenapyr & $10 \mathrm{SC}$ & Lepido & 0.01 \\
\hline 6. & Fipronil & $5 \mathrm{SC}$ & Regent & 0.01 \\
\hline 7. & Flubendiamide & $39.35 \mathrm{SC}$ & Fame & 0.01 \\
\hline 8. & Acephate & $75 \mathrm{SP}$ & Asataf & 0.05 \\
\hline 9. & Pyridalyl & $10 \mathrm{EC}$ & Pleo & 0.015 \\
\hline 10. & Control (Plain water) & & & \\
\hline
\end{tabular}


Table.2 Assessment of protection efficiency of different treatments and avoidable loss in cabbage crop during Rabi, 2015-16

\begin{tabular}{|c|c|c|c|c|c|c|c|c|}
\hline S. No. & Treatments & $\begin{array}{r}\text { Conc } \\
.(\%)\end{array}$ & $\begin{array}{c}\text { Yield of } \\
\text { healthy } \\
\text { heads (q ha- } \\
\left.{ }_{1}\right)\end{array}$ & $\begin{array}{c}\text { Protection } \\
\text { efficiency }(\%)\end{array}$ & $\begin{array}{c}\text { Total } \\
\text { avoidable } \\
\text { losses }\left(\mathbf{q} \text { ha }^{-1}\right)\end{array}$ & $\begin{array}{c}\text { Per cent } \\
\text { avoidabl } \\
\text { e losses }\end{array}$ & $\begin{array}{l}\text { Total increase } \\
\text { in yield over } \\
\text { control }\left(\mathbf{q} \mathrm{ha}^{-1}\right)\end{array}$ & $\begin{array}{c}\text { Per cent } \\
\text { increase in } \\
\text { yield over } \\
\text { control }\end{array}$ \\
\hline 1. & Spinosad $45 \mathrm{SC}$ & 0.01 & 195.67 & 100.00 & 0.00 & 0.00 & 57.17 & 41.28 \\
\hline 2. & Indoxacarb $14.5 \mathrm{SC}$ & 0.01 & 192.23 & 98.24 & 3.44 & 1.75 & 53.73 & 38.80 \\
\hline 3. & Chlorantranoliprole $18.5 \mathrm{SC}$ & 0.005 & 175.30 & 89.58 & 20.37 & 10.41 & 36.80 & 26.57 \\
\hline 4 & Emamectin benzoate $5 \mathrm{SG}$ & 0.005 & 180.95 & 92.47 & 14.72 & 7.52 & 42.45 & 30.64 \\
\hline 5. & Chlorfenapyr $10 \mathrm{SC}$ & 0.01 & 172.23 & 88.02 & 23.44 & 11.97 & 33.73 & 24.35 \\
\hline 6. & Fipronil 5 SC & 0.01 & 175.20 & 89.53 & 20.47 & 10.46 & 36.70 & 26.50 \\
\hline 7. & Flubendiamide $39.35 \mathrm{SC}$ & 0.01 & 184.47 & 94.27 & 11.20 & 5.72 & 45.97 & 33.19 \\
\hline 8. & Acephate 75 SP & 0.05 & 158.60 & 81.05 & 37.07 & 18.94 & 20.10 & 14.51 \\
\hline 9 & Pyridalyl 10 EC & 0.015 & 155.47 & 79.45 & 40.20 & 20.54 & 16.97 & 12.25 \\
\hline 10 & Control & 0.00 & 138.50 & 70.78 & 54.70 & 27.95 & 0.00 & 0.00 \\
\hline \multicolumn{6}{|c|}{$\begin{array}{l}\text { S.Em } \pm \\
\text { C.D. }(P=0.05)\end{array}$} & \multicolumn{3}{|c|}{$\begin{array}{c}3.03 \\
9.01\end{array}$} \\
\hline
\end{tabular}


Table.3 Comparative economics of insecticidal treatments against diamondback moth,

Plutella xylostella (L.) on cabbage crop during Rabi, 2015-16

\begin{tabular}{|c|c|c|c|c|c|c|c|c|}
\hline S. No. & Treatments & $\begin{array}{c}\text { Conc. } \\
(\%)\end{array}$ & $\begin{array}{c}\text { Yield of } \\
\text { healthy heads } \\
\left(q \text { ha }^{-1}\right)\end{array}$ & $\begin{array}{c}\text { Increase in yield } \\
\text { over control (q } \\
\left.\text { ha }^{-1}\right)\end{array}$ & $\begin{array}{l}\text { Return of } \\
\text { increased } \\
\text { yield (Rs) }\end{array}$ & $\begin{array}{l}\text { Total cost / } \\
\text { expenditure } \\
\text { (Rs) }\end{array}$ & $\begin{array}{c}\text { Net } \\
\text { return } \\
\left(\operatorname{Rs~ha}^{-1}\right)\end{array}$ & $\begin{array}{l}\mathrm{B}: \mathrm{C} \\
\text { ratio }\end{array}$ \\
\hline 1. & Spinosad 45 SC & 0.01 & 195.67 & 57.17 & 85755 & 7080 & 78675 & 11.11 \\
\hline 2. & Indoxacarb 14.5 SC & 0.002 & 192.23 & 53.73 & 80595 & 6940 & 73655 & 10.61 \\
\hline 4 & Emamectin benzoate $5 \mathrm{SG}$ & 0.002 & 180.95 & 42.45 & 63675 & 13050 & 50625 & 3.87 \\
\hline 5. & Chlorfenapyr 10 SC & 0.05 & 172.23 & 33.73 & 50595 & 2777 & 47818 & 17.21 \\
\hline 7. & Flubendiamide $39.35 \mathrm{SC}$ & 0.01 & 184.47 & 45.97 & 68955 & 7905 & 61050 & 7.72 \\
\hline 8 & Acephate 75 SP & 0.05 & 158.60 & 20.10 & 30150 & 2810 & 27340 & 9.72 \\
\hline 9 & Pyridalyl 10 EC & 0.015 & 155.47 & 16.97 & 25455 & 11362 & 14093 & 1.24 \\
\hline 10 & Control & & 138.50 & 0.00 & 0.00 & 0.00 & 0.00 & 0.00 \\
\hline
\end{tabular}




\section{APPENDIX-I}

Table.4 Details of economics of insecticidal treatments in 2015-16

\begin{tabular}{|c|c|c|c|c|c|c|c|}
\hline S.No. & Treatments & Conc. $(\%)$ & $\begin{array}{c}\text { Quantity of } \\
\text { insecticides } \\
\text { needed } \\
\text { (l/ kg) }\end{array}$ & $\begin{array}{l}\text { Rate per } \\
\text { l/ kg (Rs) }\end{array}$ & $\begin{array}{c}\text { Cost of } \\
\text { insecticides } \\
\text { (Rs) }\end{array}$ & $\begin{array}{l}\text { Cost of } \\
\text { labour } \\
\text { (Rs) }\end{array}$ & $\begin{array}{c}\text { Total } \\
\text { expenditure } \\
\text { (Rs) }\end{array}$ \\
\hline 1. & Spinosad 45 SC & 0.01 & 0.33 & 16000 & 5280 & 1800 & 7080 \\
\hline 2. & Indoxacarb 14.5 SC & 0.01 & 1.03 & 4990 & 5140 & 1800 & 6940 \\
\hline 3. & Chlorantranoliprole 18.5 SC & 0.005 & 0.41 & 16000 & 6560 & 1800 & 8360 \\
\hline 4 & Emamectin benzoate $5 \mathrm{SG}$ & 0.005 & 1.50 & 7500 & 11250 & 1800 & 13050 \\
\hline 5. & Chlorfenapyr $10 \mathrm{SC}$ & 0.01 & 1.50 & 1985 & 2977 & 1800 & 2777 \\
\hline 6. & Fipronil 5 SC & 0.01 & 3.00 & 1185 & 3555 & 1800 & 5355 \\
\hline 7. & Flubendiamide $39.35 \mathrm{SC}$ & 0.01 & 0.37 & 16500 & 6105 & 1800 & 7905 \\
\hline 8 & Acephate $75 \mathrm{SP}$ & 0.05 & 1.00 & 1010 & 1010 & 1800 & 2810 \\
\hline 9 & Pyridalyl 10 EC & 0.015 & 2.25 & 4250 & 9562 & 1800 & 11362 \\
\hline 10 & Control & - & - & - & - & - & - \\
\hline
\end{tabular}

* Cost of head of cabbage at prevailing market price at the time of harvesting was Rs. $1500 \mathrm{q}^{-1}$

* It includes cost of insecticides and labour charges @ Rs 200/labour / days (3 labour / spray /ha) 


\section{Economics of treatments}

The data presented in table, revealed that the maximum benefit cost ratio 17.21 was recorded in the plots treated with chlorfenapyr followed by spinosad 11.11 and indoxacarb 10.61. in the treatments of acephate, fipronil, flubendiamide and chlorantraniliprole, the benefit: cost ratio was $9.72 ; 9.28 ; 7.72$; and 5.60; respectively. The minimum benefit cost ratio 1.24 was recorded in the treatment of pyridalyl due to their higher cost followed by emamectin benzoate 3.87. the order of effectiveness of insecticides on the basis of benefit: cost ratio was found to be chlorfenapyr $(0.01 \%)>$ spinosad $(0.01)>$ indoxacarb $(0.01)>$ acephate $(0.05 \%)>$ fipronil $(0.01 \%)>$ flubendiamide $(0.01 \%)>$ chlorantraniliprole $(0.005 \%)>$ emamectin benzoate $(0.005 \%)>$ pyridalyl $(0.015 \%)$.

\section{Acknowledgements}

I am very grateful to our group members and Advisor for their great support to conducted experimental trial.

\section{References}

Anonymous. Directorate of Horticulture, Government of Rajasthan, Jaipur, Rajasthan, 2010.
Anonymous. Food and agriculture organization. FAO. Org, 2012.

Anonymous. National Horticulture Board. www.nhb.com, 2013.

Ameta, O.P. and Bunker, G.K. 2007. Efficacy of flubendiamide 480 SC against diamondback moth, Plutella xylostella (L.) in cabbage and its effect on natural enemies under field conditions. Pestology, 30 (6): 21-24.

Gill, C.K. Kaur, S. and Joia, B.S. 2008. Efficacy of new insecticides for the management of diamondback moth, Plutella xylostella (L.) on cauliflower and cabbage. Journal of Insect Science, 21 (2): 171-177.

Kumar, A. Satpathy, S. Shivalingaswamy, T.M. and Rai, M. 2007. Field efficacy of indoxacarb against diamondback moth, Plutella xylostella (L.) on cabbage. Pestology, 31 (4): 41-46.

Meena, S.C. and Singh, V. 2010. Bio-efficacy of insecticides against diamondback moth, Plutella xylostella (L.) on cabbage, Brassica oleracea var. capitata L. National Conference on Plant Protection in Agriculture, ARS, Durgapura, Jaipur, pp. 227-228.

Pradhan, S. 1964. Assessment of losses by insect pests of crops and estimation of insect population. Entomology in India, pp. 17-58.

\section{How to cite this article:}

Purushotam Sharma, Hitesh Jangir, Deepika Yadav and Sanwar Mal Jat. 2020. Economics of Different Insecticidal Treatments against Diamondback Moth on Cabbage. Int.J.Curr.Microbiol.App.Sci. 9(02): 2327-2334. doi: https://doi.org/10.20546/ijcmas.2020.902.264 